\title{
Chapter 7 \\ International partnerships of women for sustainable watershed governance in times of climate change
}

\author{
Patricia E. (Ellie) Perkins and Patricia Figueiredo Walker
}

\section{Introduction}

This chapter describes and assesses collaborative research with women actively engaged in local and global community engagement processes for water management in times of global climate change. As an equity-focused response to climate change, the interrelated networks and initiatives described in this chapter involve organizations and individuals in Brazil, Mozambique, South Africa, Kenya, and Canada. ${ }^{i}$ These collaborations are focused on strengthening low-income women's voices, and legitimizing their knowledge and action within water management institutions and processes.

The theoretical framework for this analysis links the three main themes of feminist political ecology, as described in Dianne Rocheleau's foundational book: gendered environmental knowledges, rights and responsibilities, and politics and grassroots activism (Rocheleau, Thomas-Slayter, and Wangari 1996; Elmhirst, 2011). It also reflects what Ariel Salleh, citing Maria Mies and Veronika Bennholdt-Thomsen, calls "the methodology of working with the 'view from below'... (which represents) capacity building for the global North (Salleh 2009:292, 304). As Salleh notes,

It is surely a good time now, for professionals and global justice activists to sit down and talk together, and for both to talk with people who have a developed capacity for eco-sufficiency. But in this, there is a respectful caveat to observe too; as Australian Aboriginal activist Lilla Watson put it: If you have come to help me, you are wasting your time. But if you have come because your liberation is bound up with mine, then let us work together (2009:307-308).

Rather than emphasizing the theoretical and academic contributions of feminist political ecology, this chapter thus focuses on collaborative local and global participatory methods for building social-environmental change - the "how" of grassroots Feminist Political Ecology.

\section{Importance of women's knowledge and engagement}

The initiatives discussed in this chapter provide some examples of how women's experiences and knowledge relate to watershed governance and to global climate change. In a feminist political ecology sense, these stories link gendered environmental knowledge with rights, responsibilities, politics and grassroots activism at various scales, both within and across watersheds. 
Watersheds are examples of fractal organization, which occurs throughout nature (veins in leaves, ripples on sand, etc.), where patterns at small scales are repeated at larger scales, and interrelationships across scales emerge organically. In the same way and through this collaborative research, we argue that women's expertise and understanding of social and ecological processes at the local, household, and inter-household scales provide the basic knowledge and insights for watershed management that can be applied at larger (national and international) scales.

Women have special contributions to make towards watershed governance and waterrelated climate change adaptation because of gendered differences in their positional knowledge of ecological and water-related conditions. Although women fill multiple roles at home as well as in local communities (and of course gender combines with other aspects of identity including ethnicity, class, and race in affecting every person's political position), women in general are underrepresented, and in many cases excluded, from political and environmental decision-making processes. The dominant climate change narrative often presents women as "victims, rather than as agents capable of contributing to solutions" (Terry 2009, 3). However, in rural areas throughout Asia, Africa, and in many parts of Latin America, women are the principal managers of natural resources, which they and their families rely on for their livelihoods. More and more, climate change and climate variability are negatively impacting women's everyday lives and their ability to perform these daily tasks. "Women and women-headed households are particularly vulnerable to the combined impacts of food price rises, insecurity, and changes to climate" (Toulmin 2010, 150).

Urban dwellers may be even more vulnerable to extreme weather events than those living in rural areas, and again women are most affected. In particular, those living in low income, dense, and flood-prone slums are experiencing more intense and longer floods and landslides. In many countries in the Global South, the increasing frequency and magnitude of extreme weather events may cause even more socio-ecological disasters in both urban and rural areas (Mirza 2003). These disproportionately impact women, who typically possess fewer financial and social resources than men and are therefore more vulnerable to the adverse impacts of climate change. Both at work and at home, "as gendered work and family responsibilities make poor women the main cleaners and caregivers, poor women are the ones most affected by water issues" (Moraes and Perkins 2009). For example, a recent study found that natural disasters on average kill more women than men or kill women at an earlier age, due to their "everyday socio-economic status" (Neumayer and Plümper 2007, 1).

This indicates that women's vulnerability to climate change and variability is strongly influenced by their gender roles, which undermine their ability to cope with and adapt to climate change. The IPCC's Third Assessment Report (TAR) describes adaptive capacity as "the ability of a system to adjust to climate change (including climate variability and extremes), to moderate potential damages, to take advantage of opportunities, or to cope with the consequences" (IPCC 2007, xx). One way to build women's adaptive capacity is to address their vulnerability by improving their socioeconomic status and access to 
resources. Decades of institutionalized "development" efforts, however, have been unable to redress such gender inequities, which are now being exacerbated by climate change.

Acknowledging and addressing the many significant interactions between climate change and gender inequalities is fundamental for the development of climate policy and adaptation strategies that are effective and gender-just and that do not further aggravate existing inequities. "Interventions that create greater awareness and understanding of the complex links between gender equality and the environment can help to build the capacity of the poor, especially poor women, to adapt to the impacts of, and take action on climate change" (CIDA 2002, 3).

Education and involvement of women in formal decision-making processes can strengthen their adaptive capacity. This also furthers climate justice, which involves the principles of avoiding dangerous climate change, forward-looking responsibility, putting the most vulnerable first, and fair participation of all (Paavola, Adger, and Huq 2006).

A growing number of grassroots climate change initiatives focus on laying the groundwork for broader political participation, which can facilitate long-term, selfdirected, and community-based climate change defense strategies (Ensor and Berger 2009). These locally based approaches promote capacity building, community empowerment, social inclusiveness, and participation. There is an extensive literature on the theoretical and practical grounding for such participatory processes (e.g. Sagoff 1998; Holland 1997; van den Hove 2000; Faucheux and Hue 2001; Wilson and Howarth 2002; and Perkins 2003).

Bottom-up climate change organizing "has been seen as the cornerstone of an inclusive/ deliberative approach to planning and governance that places stakeholders' knowledge, opinions and aspirations at the centre of decision-making, as opposed to a managerialist (technical-rational) approach in which professional expertise and bureaucratic control shape policy and practice. Participation has been promoted both instrumentally, as a 'means' of ensuring that decisions are better geared toward their objectives, and as an empowering 'end' in itself, ceding communities greater control over the decisions that affect their lives (Few, Brown and Tompkins 2007, p. 48). In contrast to top-down policies such as international carbon trading or REDD (Reducing Emissions from Deforestation and Degradation) which require elaborate international rules and institutional structures, bottom-up approaches encourage communities to use local skills and knowledge to identify their vulnerabilities to climate change and develop adaptation strategies that are tailored to their needs. Building women's adaptive capacity, in particular - besides assisting individual women to become politically active and develop their leadership potential - can contribute to enhancing the adaptive capacity of communities, given the significant roles women hold (e.g. for water provision and food production).

As Ensor and Berger point out, climate adaptation should reduce women's vulnerability, which helps to meet both climate justice and broader development goals $(2009,16)$.

Moreover, climate change education, community organizing, and leadership development 
increase the "voice" of marginalized people as part of a global movement to address global inequities and the fundamental drivers of climate change. This goes far beyond "adaptation" to include broader political action as well. As feminist political ecologists demonstrate (see also Salleh 2009), when women share their own environmental knowledge, this often leads them to make human rights-based claims for political rights, which inevitably changes politics more broadly.

Community-based education and organizing are fundamental to creating the conditions for local knowledge to be shared and utilized, through equitable democratic participation. Building inclusive governance structures and strengthening the role of civil society, especially women, in water governance are essential components for addressing vulnerability and fostering resilience and sustainability in urban centers as well as rural areas. According to the Intergovernmental Panel on Climate Change, adaptation is shown to be successful and sustainable when linked to effective governance systems, civil and political rights and literacy (Brooks, Adger, and Kelly 2005, 161). Non-governmental organizations in the Global South and in marginalized areas of the North have expertise on how to do this. Their knowledge is potentially shareable and may be inspirational for other localities.

Community-based environmental education initiatives can serve as the basis for a climate change intervention approach that is progressive, constructive, and democratic. This is particularly true when such initiatives are relevant and interesting for local residents and increase their job opportunities, knowledge of watershed issues, understanding of basic political and ecological principles, and confidence to express and act on their views. This community action in turn, increases the resilience and sustainability of watershed and climate change decision-making processes. It also lays the groundwork for community organizing and extension of the environmental education activities to larger constituencies in other localized areas affected by climate change.

As examples, we will discuss the results of two international projects- the Sister Watersheds project with Canadian and Brazilian partners (2002-2008), and a Climate Change Adaptation in Africa project with partners in Canada, Kenya, Mozambique, and South Africa (2010-2012). Both projects have demonstrated the wide applicability of local-level efforts in vulnerable communities in Toronto and in African and Brazilian cities to address equity challenges by developing strategies and materials to increase the knowledge, interest, and engagement of local residents on water-related and climate change issues, focusing in particular on women and youth.

\section{Sister Watersheds: education for equitable water governance in Brazil and Canada}

As in many countries, deforestation and environmental degradation, rural-urban migration, and continued urbanization exacerbate Brazil's vulnerability to climate change. New weather patterns have caused periodic flooding in Rio de Janeiro and São Paulo, damage to housing and infrastructure, and deaths - more than 900 in January 2011, nearly 400 in March 2013. 
While Brazil has a progressive watershed management system, requiring participation by civil society representatives on watershed committees, low-income people and women in particular are underrepresented. Watershed committees are formed "so that water users can collectively help to decide issues of allocation, infrastructure and regulation at the watershed level" (Hinchcliffe et.al. 1999; Perkins 2004). However, social norms and perceptions, overwork, and illiteracy may impact women's ability to participate in these committees. For example, if water management is presented as a technical issue instead of a social one, women may feel and actually be excluded from policy discussions. But special training and organizing can support women to participate actively and effectively in articulating their views, insights and perspectives on local climate change and waterrelated challenges.

Clearly the challenges of how to elicit and motivate women's effective public involvement among economically-stressed groups in civil society, how to easily convey and discuss complex ecological issues in public workshops, and how to build bridges between disadvantaged local communities and public officials at the watershed level, know no boundaries: this is a global problem.

The Sister Watersheds project (2002-2008) linked universities and NGOs in Canada and Brazil in developing strategies and materials for increasing the knowledge, interest and engagement of local residents on water-related issues, focusing on low-income neighborhoods in São Paulo and Toronto, and in particular on low-income women. This $\$ 1.3$ million project - funded by the Canadian International Development Agency (CIDA) through the Association of Universities and Colleges of Canada - combined student exchanges, research, community engagement, and "capacity-building" in local communities and nearby universities. Its novel conceptualization and design were developed by progressive Brazilian environmental educators-Dr. Marcos Sorrentino (a professor at the University of São Paulo who was subsequently appointed director of environmental education in the Brazilian federal Ministry of the Environment) and Larissa da Costa of the Ecoar Institute for Citizenship (Ecoar), who subsequently became environmental education director at the World Wildlife Fund in Brasilia. The project's design evolved throughout its implementation by organizers at Ecoar, a leading environmental education NGO based in São Paulo, and at York University in Toronto, Canada.

Addressing the lack of participation by civil society representatives, especially women, in water sector governance, which of course has parallels in every country including Canada, was a primary objective of the Sister Watersheds project. The project developed and tested training programs by conducting workshops led by its local NGO partners with more than 1450 participants, approximately two-thirds of them women, and by partnering with other community organizations on environmental and watershed management education. For example, staff from Ecoar contacted groups of elementary school teachers, public health extension agents, youth groups, and other community-based workers, and provided in-service training for them about water and health, basic ecology, and public policy questions related to water in their local communities. The various training programs were designed to be specifically appropriate for groups of women, children, 
youth, health agents, school groups, teachers, film/culture/music/arts organizations, and Agenda 21 groups. This helped to link non-governmental, community, and government institutions into watershed governance, by showing participants how their experience and knowledge of the watershed were important in larger political processes. The workshops focused on water management, environmental education, community development, and democratic participation, with particular emphasis on gender and socioeconomic equity. The methodologies, techniques, and materials developed for these workshops and training programs - made freely available to other organizations through publications and websites - contributed to the capacity of project partner organizations, individual staff members, and students to continue their work on watershed policy issues.

The curriculum materials and techniques developed by the project were tested and finetuned in more than 220 workshops designed and led by project staff, student interns, and university exchange students in three watersheds - the Piracicaba and Pirajussara watersheds in São Paulo, Brazil, and the Black Creek watershed in Toronto, Canadawhere university campuses are located near low-income residential areas or favelas (refer to map in Figure 7.1). All the project workshops were conducted with low-income residents, and the workshop methodologies were designed to build participants' confidence about their knowledge and its importance, the need for their intervention as representatives of their community, and their ability to participate in watershed governance processes. All of the Brazilian workshop participants were potential civil society participants in watershed committees, which were well-organized in their areas as a result of Brazil's 1998 water law. Some of the academic partners in the project held positions of responsibility on technical groups connected with the watershed committees, so inter-personal connections also helped to build workshop participants' engagement.

Figure 7.1 [insert map of São Paulo watersheds and university campuses here]

The outreach materials developed by the project include an illustrated Manual on Participatory Methodologies for Community Development containing a set of workshop activities and background materials for participatory community environmental education programs and training sessions with marginalized community members focusing on water and other environmental topics and equity issues ( Teixeira, Ferraz Duarte, and Morimoto2008); an illustrated guide with practical exercises focusing on urban agroecology (Gonçalves et al. 2008); a full-color socio-environmental atlas bringing together ecological, hydrological, and social information about one local watershed in a series of interactive maps which was made available to local political and watershed committee leaders; videos about the project and about the history and environment of the watersheds (Projeto Bacias Irmãs 2007a, 2007b); a publication outlining Agenda 21 activities in schools; and several blogs and websites with materials and discussionstarters on watershed topics, as well as a book and many journal articles, masters' papers, and other academic publications contributing to the literature on participatory watershed education in Brazil and in Canada (Sister Watersheds Final Report 2008).

One workshop participant summed up the project's educational activities this way: "O rio córrego como protagonista é a pauta principalmente em área urbana, portanto, toda a 
discussão em torno disso é necessária e muito importante. A maneira como está sendo apresentada no curso me parece bastante satisfatória. Tem funcionado, na verdade como condutor de reflexão e discussão enriquecendo conhecimentos" ("The river as protagonist is the main agenda, principally in an urban area, therefore all the discussion about this is necessary and very important. The way this is presented in the course seemed very satisfactory to me. It functioned in fact like a conductor of reflections and discussion, enriching our knowledge.”) (Sister Watersheds Final Report 2008, appendix 1).

A 14-year-old participant in a series of project workshops commented, "Para muitos que hoje estão aqui, esse é apenas o final do projeto, mas para mim isso é o começo. Vocês semearam em nós o respeito e o zelo para com o meio ambiente e o meu maior desejo é disseminar esse carinho e cuidado com o planeta. Obrigada por tudo e obrigada a todos que juntos estão trabalhando por um mundo melhor" (Emanuela Aluna da EMEF Vera Lucia Fusco Borba "- 14 anos)" ("For many of us here today, this is just the end of the project, but for me this is the beginning. You have planted in us respect and zeal for the environment, and my main desire is to spread this affection and care for the planet. Thank you for everything, and thanks to all who are working for a better world." - Emanuela, student in Vera Lucia Fusco Borba school, age 14)

(Projeto Bacias Irmãs 2008, 25).

Community environmental perception surveys conducted by the project in each of the Brazilian watersheds established a database of information on public priorities and views on watershed issues. A socio-environmental atlas gathered and made available a wide range of information on ecological, hydrological, social and political circumstances in the watershed - information which proved very useful to public officials and watershed committee members in understanding the watershed as a whole. The nearly 1,500 (at least 942 female and 536 male) participants in workshops conducted by the project gained familiarity and experience with water-related issues and their own ability to influence water management and policy through participation in existing watershed committee structures, as well as community organizing, community arts, sharing their knowledge and care for the local streams and rivers.

This project helped both its university and NGO participants to bridge the gap between academic and community-based methods of environmental education. Graduate exchange students studied and contributed to local training programs; faculty members wrote about the theoretical and practical benefits of public participation in watershed management; NGOs supervised students who received academic credit for their community-organizing work; professors led local watershed governance technical committees; innovative methods for environmental education were shared internationally. This collaboration allowed new perspectives on water management to evolve, with benefits for all participants' training/education programs. The University of São Paulo, York University and Ecoar developed dozens of new partnerships with other community organizations as a result of this project. Students, both in Brazil and in Canada, played a crucial role in developing the linkages between academic institutions and community-based NGOs. Both locally and internationally, students sought out community organizations for their research and field experiences, and shared the results of their work with both academic 
and non-academic audiences. The student exchanges sponsored by the project thus fuelled its interdisciplinary and educational bridging contributions. The project also showed that future applied research projects and community action on watershed governance are needed, in both Brazil and Canada, to build equitable watershed-based networks of civil society, academic and government actors in order to increase women's leadership and participation in watershed-scale climate-related challenges.

The methods and approach of the Sister Watersheds project proved to be applicable to climate change education and organizing in Canada as well as in Brazil. Beginning in the summer of 2006, using some of the workshop ideas and materials generated in Brazil, several teams of York University graduate assistants and volunteers conducted a series of environmental education workshops with young people from the Jane-Finch neighborhood. This neighborhood, one of the most stigmatized in Canada and widely known for its ethnically-diverse population, crime rate, and poverty as well as infrastructure and urban planning problems, ${ }^{\text {ii }}$ borders York University across Black Creek, a tributary of the Humber River (refer to map in Figure 7.2).

Figure 7.2 [insert map of Black Creek, York University and Jane-Finch neighborhood here]

Working together with local organizations, students and project volunteers incorporated environmental education into existing summer-camp and after-school programs in a variety of local community centers and other venues. This programming contributed environmental content to the summer experiences of the young people and brought an environmental focus into the ongoing work of local organizations, while giving York University students practical opportunities to test their environmental education skills. The materials and workshop ideas generated for these summer programs served as the basis for Sister Watersheds graduate assistants' participation with a local community development non-governmental organization, Doorsteps Neighborhood Services, in its after-school programs for children aged 8 to 13. Ecoar organizers from Brazil visited the Doorsteps programs, which enriched programming ideas, materials, and techniques on both sides. This partnership showed that there are far more international commonalities than differences in doing community-based environmental education with youth and women.

Most of the neighborhood youth workshop participants were girls, since the boys tended rather to gravitate towards sport-centered programs, and parents in the area, largely new Canadians, were more concerned to have their daughters enrolled in organized programming. (When the environmental education included pulling on hip-waders and taking samples of the water in Black Creek for benthic invertebrate monitoring, however, the boys were very interested in joining in). The students and staff leaders of the workshops were mainly women, by a ratio of more than 4 to 1 .

One particular contribution of the York/Black Creek "sister watershed" was the evolving art-based "Black Creek Storytelling Parade," a participatory performance walk held periodically that follows the route of stormwater from the York University campus to the 
banks of Black Creek, using different storytellers from neighborhood organizations to recount the history of the natural and built environment. Various creative strategiescostumes, sidewalk chalk, and percussion instruments - are employed to engage the audience. The content of the stories includes natural, cultural and political dimensions: the land claim of the Mississauga of the New Credit First Nation covering the entire City of Toronto, the Haudenesaunee village buried under electric lines just south of the campus, how the creek acts as a cultural divide between two very distinct neighborhoods, and local ecological restoration efforts as showcased by young students at a nearby elementary school. The Black Creek Storytelling Parade, which was developed by York graduate students in the area of Community Arts Practice, shakes up conventional understandings of nature by emphasizing social, cultural and political stories - tales often left untold in the city's official chronicles. This helps build an ecological imaginationthe capacity to imagine how people could be living in such a way that humans, plants, and animals thrive in ecologically sustainable and socially just futures. It does so by sparking dialogue and dreams for a restored creek - restored not just in terms of greenery and cleanliness, but also in terms of social and cultural importance.

The importance of community watershed awareness and water infrastructure was underscored for the York University and Jane-Finch neighborhood in August 2005, when a torrential thunderstorm caused massive flooding. Black Creek, normally a slow trickle, became a roaring torrent that overwhelmed and washed out the 1950s-era culvert built to carry it under Finch Avenue, a four-lane arterial roadway in northwest Toronto (refer to photo in Figure 7.3). Over a period of several hours, the creek carved a chasm about 50 meters wide and ten meters deep. Repairs, including a new bridge for Finch Avenue, cost more than \$U.S.3 million and took nearly six months to be completed. During this time, commuter traffic and city buses were diverted through the York University campus, causing major disruptions for the university and local residents alike.

Figure 7.3 [insert photo of the 2005 Black Creek washout of Finch Avenue here] Photo credit: Lucas Oleniuk / Getstock.com

In 2008, the Jane-Finch Community and Family Centre, a local social services organization, began applying for funding to develop jobs training for local residents in the area of energy retrofit evaluation, community garden development and local food production, and other "green jobs" such as insulation and renewable energy construction. The vision for this project derived from recognition that low-income people are often the most negatively affected by environmental problems, and that poverty, social justice and the environment are interlinked. iii The successful Green Change Project they created, with funding from various programs of the City of Toronto and the Province of Ontario as well as the United Way, an umbrella social services NGO, has won awards and is developing new models for training Green Change Agents-local Jane-Finch residents who gain skills, references, confidence and a forward-looking perspective which increases their employment opportunities (JFCFC 2013). York University alumni, students and faculty are involved in developing the curriculum, teaching workshop modules, and serving on the advisory board for the Green Change Project. At a gala fundraiser in March 2011, keynote speaker Majora Carter ${ }^{\text {iv }}$ overviewed similar initiatives 
in low-income neighborhoods throughout the U.S. where community development, green job creation, and ecological restoration are combining to produce powerful synergies. When community-based organizations can patch together funding through a range of government job-creation, social assistance and environmental programs, they may be able to generate training programs and create local jobs in environmental remediation, alternative energy projects, food production/processing, and other sectors.

Said the first Green Change Project coordinator, Rosemarie Powell, "The neighborhood of Jane and Finch is plagued with violence due to socio-economic struggles and the endemic rate of poverty and underemployment. On the other side of the coin is the emerging trend and related opportunities in the green economy. Our vision is for a Centre for Green Change in the heart of Jane and Finch, where residents and youth concerned about the protection of the environment are engaged and mobilizing others as they increase their knowledge and skills and initiate individual and collective actions toward building a healthy, safe, prosperous, and environmentally friendly neighborhood" (Powell $2010,4,6)$.

The Green Change Project was developed and is led by community activists, mainly women; by June 2013 about two-thirds of the Green Change Agents trained were women. Green Change Agent Janet Campbell, who was hired to work as a local environmental educator and led meetings on the community's right-to-know about toxics emitted locally by industrial polluters proudly said, "Thanks to the Green Change Project, I am actively involved in taking care of our planet" (JFCFC 2012, 2).

As part of a subsequent international research/linkage project, two York University graduate students wrote overviews of climate change and water-related equity issues in Toronto, in preparation for their exchange visits to African cities to study similar questions there (Lorimer 2011; Todd 2011). One of these Toronto studies was a history of the Green Change Project, which project organizers could use on their website and in future grant proposals; the other was an overview of the impacts of climate change and adaptation policies in Toronto through an equity / climate justice lens.

The 2005 Black Creek flood was a graphic example of how increasingly common extreme weather events, in conjunction with aging infrastructure, urban sprawl (including campus development) and increasingly rapid rainfall runoff due to impermeable urban surfaces, can have costly and traumatic effects on everyone in the watershed. Climate change affects all of us together! Sharing social knowledge at the watershed level greatly facilitates adaptation to such new realities. In 2014, this neighborhood-scale project is still generating local environmental education, climate adaptation, and green community development in the Jane-Finch area, bringing local community organizers and residents into collaboration with students and faculty from York University.

\section{Climate Change and urban water governance in Africa}

Following the close of the Sister Watersheds project, contacts among several academic and civil society organization (CSO) partners in three African countries and Canada led 
to the development of a related project, entitled "Strengthening the role of civil society in water sector governance towards climate change adaptation in African cities-Durban, Maputo, Nairobi." The goal of this three-year initiative (2010-2012) was to improve watershed governance for climate change adaptation and enhance resilience and adaptive capacity of vulnerable and marginalized groups, especially women. The project was supported by the Climate Change Adaptation in Africa (CCAA) program - a joint initiative of the International Development Research Centre (IDRC) and the United Kingdom's Department for International Development (DFID). This project's methodology included collaboration between students, civil society organizations, and academics as well as community-based research and environmental education. Project partners based in universities and several CSOs in Kenya, Mozambique and South Africa worked together to achieve the following objectives: 1 . To characterize the institutional framework for urban water governance in the three cities, and explain how different actors within this framework cope with climate change and variability; 2. To identify and test viable alternatives for enhancing civil society's role towards adaptation to climate change and variability by vulnerable groups (e.g. by developing education, training and awareness programs); and 3. To share widely the knowledge generated for potential adoption by other cities in Africa.

According to the Intergovernmental Panel on Climate Change (IPCC), "Africa is one of the most vulnerable continents to climate change and climate variability. This vulnerability is exacerbated by existing developmental challenges such as endemic poverty, limited access to capital, ecosystem degradation, and complex disasters and conflicts" (IPCC 2007). Income inequality in South Africa, Mozambique, and Kenya is among the largest in the world. In all three countries, equity struggles related to water are growing in social, political and ecological significance; this is both a symptom and a cause of urban vulnerabilities related to climate change.

In Mozambique, climate change is causing coastal erosion, the destruction of mangroves and resulting threats to the locally-important shrimp fishery, periodic flooding along scenic coastal roadways, saltwater intrusion and wind erosion. In cities there is desertification in food-producing areas, flooding in coastal slum areas, degradation of water quality in wells and potable water scarcity. The sea level of the Indian Ocean is rising, with concomitant coastal management problems in Maputo municipality (UN Habitat 2010, 2). The United Nations Habitat Cities in Climate Change Initiative, which has begun a pilot project in Maputo, emphasizes local government capacity-building, policy dialogue, climate change awareness, public education, and developing coordination mechanisms between all levels of government as priorities to help address these risks. Mozambique's national water law (1991) considers all water as state-owned, to be governed by the state for the benefit of the population, with water access for people, sustainability, and stakeholder participation as priorities. Four water basin committees have been established in Mozambique on the same general model as Brazil.

As in Mozambique, South Africa is implementing watershed committees or "catchment management agencies" (CMAs) to decentralize decision-making and create a framework for integrating the needs of all stakeholders in water governance. The municipal 
government in Durban, South Africa has developed a local climate change adaptation strategy; like Maputo, Durban faces coastal inundation and storm surges related to sea level rise, hotter temperatures and heat waves, changed rainfall and storm patterns, slum flooding and reduced drinking water supplies due to climate change. Local policy initiatives rely for effectiveness on awareness and capacity regarding climate change risks and adaptive responses in civil society. Environmental education and confidencebuilding through capacity-raising are recognized as crucial needs in this process; for example, the Inkomati CMA, in a watershed north of Durban which includes Maputo, has initiated outreach programs targeting farmers, women and youth. This type of action research is well developed in Durban, partly due to the work of the Centre for Civil Society at the University of KwaZulu-Natal and its partner civil society organizations (CSOs).

In Nairobi, severe infrastructure needs are being exacerbated by water supply fluctuations and slum flooding related to climate change. Just as in Maputo and Durban, environmental awareness and education to promote more equitable governance processes are required. As noted by the Kenyan delegation to the $2007 \mathrm{UN}$ conference on climate change in Nairobi, Kenya's adaptation priorities include education, good governance, human resources development and training, institutional capacity building and management change, public finance improvement, and better national resources management.

Our Climate Change Adaptation in Africa (CCAA) project was implemented by the following community-based organizations: the Kilimanjaro Initiative (KI) and Kenya Debt Relief Network (KENDREN) in Nairobi; Women, Gender and Development (MuGeDe) and Justiça Ambiental (JA) in Maputo; and Umphilo waManzi (Water for Life) and the South Durban Community Environmental Alliance (SDCEA) in Durban. The University of Nairobi (Nairobi), Eduardo Mondlane University (Maputo), and the Centre for Civil Society at the University of KwaZulu-Natal (Durban) provided academic research coordination and student supervision for this project.

The project focused on low-income areas of each city, as these tend to be most severely affected by periodic flooding and other climate change impacts. Furthermore, residents of low-income areas often struggle to protect themselves against the impacts of extreme weather events. The capacity-building aspects of the project included training and research sponsorship for students and faculty in the partner universities; support for community-based research, workshops in low-income communities and secondary schools given by CSO staff along with university students, curriculum and materials development, and skills development within the partner CSOs; training of environmental educators and organizers; contributions to the pool of experienced and qualified community workers in each country; strengthening of all the partner institutions' capabilities to carry out international projects; and contributions to the international literature and professional knowledge concerning water issues, environmental education techniques, and community organizing for improved civil society involvement in governance. The networks built extend from local and community-based linkages 
through regional and national-level policy groupings to international academic and policy networks on civil society, watershed management, and governance.

Following internships with local CSO partners in the project, university students participated in exchange trips to other countries and also worked with CSOs there on climate justice projects. In this way, the students and the organizations gained new perspectives on different ways of meeting local challenges and on the ecological and political contexts for their work. ${ }^{\mathrm{v}}$

The political process of policy development and implementation depends on the interchange between civil society groups, researchers generating information on current realities, and government. This project attempted to challenge the conventional notion that only educational institutions "produce" knowledge. Understanding community needs, and what helps particular civil society groups to see and act to strengthen their role in democratic governance, is something in which community organizations and CSOs have eminent expertise.

One objective of this project was to demonstrate how partnerships between academics and non-academics can be very stimulating and effective. This type of partnership encourages and allows the partner CSOs to reflect on and analyze their activities and to document learning, by bringing student researchers into the CSOs as collaborators/interns. The partnerships also encourage universities to be more pragmatic about teaching and research, and to "field-test" approaches towards community organization, equity, and capacity building. Students committed to the project's goals of building participatory engagement by local people in municipal water decision-making were given practical opportunities to develop their skills, as a way of advancing each city's climate change preparedness. This project emphasized the integration and meaningful participation of women in formal decision-making processes, to increase their resilience and ability to cope with climate change.

Specific examples of how climate change responses combine well with gender-aware community organizing, all of which were explored through this project, included the following:

- The Kilimanjaro Initiative (KI), a youth-focused NGO, upgraded a sports field in Nairobi's Kibera slum, on the banks of the Nairobi River, which helps prevent housing from being flooded during extreme weather events. In addition, KI organized sports leagues including young women athletes, community forums on sustainable water management and environmental education, and community and river clean-ups. Young women's leadership was central to their organizing.

- In Durban, women activists from Umphilo waManzi and the South Durban Community Environmental Alliance coordinated "learning journeys" where government officials visited low-income neighborhoods to hear about local women's experiences with flooding, sanitation and other types of climate change stresses. This helped them to bring these views into policy discourse. 
- Maputo university environmental education students worked with intermediate school youth on after-school activities related to climate change such as neighborhood and river clean-ups, clearing drainage canals, and documentary film screenings on environmental issues. Participation by parents and teachers was also welcome. The majority of participants were women.

In the words of Mozambican environmental education student Neima Adamo, "Para que a problemática do meio ambiente seja de facto um assunto comum entre a sociedade, é fundamental que a informação sobre a necessidade de preservar e conservar o meio ambiente seja disseminada por todos os actores da sociedade nos diversos níveis sociais, desta feita entende-se Educação Ambiental não-formal às acções e práticas educativas voltadas à sensibilização da colectividade sobre as questões ambientais e à sua organização e participação na defesa da qualidade do meio ambiente." "In order for environmental issues to be a common subject in society, it's fundamental that information about the need to preserve and conserve the environment be known by all actors in society, at all social levels; in this way non-formal Environmental Education can be understood as all actions and educational practices aimed at sensitizing the community about environmental questions and organization and participation to protect environmental quality." (Adamo 2012, 29).

\section{Action to strengthen women's participation in water management}

Both the Sister Watersheds project and the CCAA project, as well as the Green Change Project, explored practical methods of increasing women's "voice" in water management processes. Table II lists and summarizes some of the ways to do this. It has been our experience that these sorts of workshops, training programs, exercises and strategies are adaptable and can be appropriate in a wide range of circumstances in both the global South and the global North.

Table II

\section{PARTICIPATORY AND INCLUSIVE PROCESSES}

Ways of bringing women into water management, starting at the community level

- Community mapping: residents collectively draw maps of important water features in the neighborhood and how extreme weather affects them; then discuss. Photo-voice: community members photograph local scenes significant to them, in relation to climate change effects, and discuss/share with government officials. Water dialogues: local residents discuss specific water issues with government officials, in forums facilitated by civil society organizations.

- Water walks / storytelling parades: using waterways as a focus, local residents and visitors tour stream beds and floodplains, stopping for special presentations on local history, wildlife, food production, music, community assets, etc. 
- Collective storytelling workshops: community groups use selected 'props' to spark creativity as they compose a joint story about the local watershed, sharing personal memories.

- Community-based water monitoring: community groups work with government authorities to monitor pollution, biostatus, and flooding/drought in local waterways.

- Water conflict mediation training: special CSO-run training programs address water conflicts (e.g. over standpipe access, fugitive emissions of pollutants, riparian rights, etc.) through skills training and information on how to access government supports.

- Water harvesting: CSOs work with household members to develop ways of retaining rainfall from roofs and yards for home and garden use, and spread related practices.

- Community gardening: CSOs locate space and train and organize community members to plant gardens for collective food production.

- Community kitchens: CSOs or churches establish kitchen space for collective food preservation, processing and cooking and for feeding vulnerable community members and buffering time pressures for women.

- Leadership training: CSOs work with government and watershed committee officials to develop inclusivity training and confidence-building workshops for women, to welcome and facilitate their participation in water governance institutions.

As noted above, these types of grassroots water and climate change programming and organizing address long-standing, difficult gender inequities which have proven intractable despite decades of work, but which are nonetheless increasingly important in times of climate change. By creating spaces within local communities where women can share their knowledge of local water and climate conditions, develop confidence and respect for each other's abilities, and work together to devise and implement solutions, this sort of watershed-based organizing addresses gendered social inequities by making and calling for fundamental changes in governance. In feminist political ecology terms, this allows women to make use of their gendered environmental knowledge to work to advance their rights and responsibilities through networked grassroots political activism.

\section{Conclusions}

Engaging women and applying their expertise is fundamentally important for long-term climate change adaptation, particularly during environmental crises. Women's knowledge of local ecological and water conditions must be shared and utilized in local, national and international decision-making processes - for reasons of both justice and efficiency. Democratic mediation of equity conflicts related to water, and sustainable long-term management of water resources, are only possible through civil society's participation in water governance. Moreover, because climate change mainly manifests itself through 
storms, floods and droughts, climate change adaptation starts within watersheds and engages various scales of ecological and social interaction.

Community-based, 'people-centered' approaches to climate change are crucial for adaptation strategies that address social and gender inequalities and allow women to serve as active agents of change in their communities. "Past history shows that the poor and vulnerable do not get a fair share of resources unless they can mobilize effectively and there is parallel pressure on the powerful to make decisions in favor of the many, not the few... This means making sure that the voices of ordinary (people) - women, men, young, old, farmers and slum dwellers - are heard loud and clear as the policies and institutions for addressing the most challenging of global problems are developed" (Toulmin 2010, 152).

Although community-based adaptation (CBA) interventions offer unique opportunities for community involvement in climate change adaptation decision-making processes, and have the power to enhance the adaptive capacity of individuals, households, and communities, the CBA approach is not perfect. CBA projects tend to have short timescales, small budgets, and limited scope -- i.e. they address some locally relevant climate change impacts, but not necessarily other contextual development challenges (Ludi et al. 2014). As with other CBA projects, the projects mentioned in this chapter faced some important limitations.

The CCAA project, for example, ran for only three years, which is simply insufficient considering the time required to identify vulnerable communities, liaise with community leaders and elders, introduce the project to the community, identify one or more direct impacts of climate change through participatory community workshops, and begin implementing the project. Similarly, the project focused on a handful of direct climate change impacts -- e.g. water scarcity, floods -- but not on other drivers of vulnerability, such as poverty. More specifically, the project did not provide assets to community members or directly help to improve their livelihoods; instead, the project focused on raising awareness of climate change, educating community members on the climate change impacts facing their communities, improving community access to information, and facilitating women's interaction with other stakeholders, including government and private actors. The 6-year Sister Watersheds project similarly focused on environmental education, confidence-building for political engagement, and local green community development. Whether these project activities were sufficient to substantially improve local people's capacity to adapt to or affect long-term changes (climatic or otherwise) is uncertain, and probably untestable. However, by strengthening local civil society organizations and reinforcing their water and climate justice related initiatives, these projects may have laid the groundwork for ongoing socio-political activism related to both climate change and deeper 'development' issues.

Cross-cultural collaboration is another area of challenge and growth for projects such as ours, and for all who intend to address climate justice. Since our work has involved communication and collaboration across various kinds of difference -- race, class, gender, the academic-grassroots divide, language, ethnicity, nationality - we have been aware of the need for sensitivity and attention to these differences throughout, and we have tried to 
create both formal and informal spaces for discussion and interpersonal sharing as a way of building trust and confidence in each other to facilitate our work together. For example, at the CCAA project's first meeting where most of the CSO and academic partners were meeting each other for the first time, we obtained special funding which allowed the African partners to visit Brazil together, make 'field visits' to see successful public engagement and green community development initiatives there, and spend informal time together as well as more formal meetings where we discussed our joint goals for our project. We scheduled a session on gender at this first meeting, so we could all 'get on the same page' regarding our understanding of gender and its importance in our project. Both the CCAA and Sister Watersheds projects involved student internships with CSOs, international student exchanges with CSOs in other countries, language instruction for exchange students, faculty field supervision of students' off-campus work, joint writing projects for students and junior faculty team members, and technical support visits to share organizing ideas from the global South in other countries including Canada - all methods for bridging various kinds of difference and building team members' experience with how to do so. Our project started from the premise that local CSOs are already doing great work so we should support them, with funding and by building local and global university connections; this meant that we avoided many cross-cultural mistakes because local organizations were in the lead.

The biggest cross-cultural challenge in any 'development' project relates to money. As long as the budget comes from an international organization with its own objectives, conditionalities, and reporting requirements, and as long as the budget is administered through a university with its special bureaucracies and regulations, projects have a constant struggle to maintain good will, solidarity, and a semblance of participatory process. We certainly encountered a number of frustrations related to funding delays and rules over the course of our work, which highlighted the importance of good language skills on the part of key project participants (the coordinator and staff responsible for finance and reporting in each partner organization), full transparency on all requirements and budget changes, and good groundwork to establish trust and a common sense of project goals and shared responsibilities. Once it feels like a privilege and challenge to be working together on a big global problem, and learning from each other, it is easier to bear the day-to-day hassles by 'keeping your eye on the prize', the real motivation for your work.

Existing development challenges - such as poverty, gender, and structural inequalitiesand inadequate infrastructure aggravate the climate vulnerability of the poor, and of many women in particular. This chapter has summarized some ways that women are working together on climate education and water governance, helping to inspire and generate related strategies in other places which address both climate-related and underlying structural inequities.

These stories demonstrate the essence of feminist political ecology - what Ariel Salleh calls an "embodied materialist understanding (which) is indispensable to the transdiscipline of political ecology....the vital citizenship politics of ecological feminism" (Salleh 2009:6). Women start in their local communities, build on their gendered local knowledge, share skills and experiences, respect leaders as they emerge, work to build 
political rights for women through grassroots activism, and communicate with others elsewhere who are facing related and similar challenges to build movements at everlarger scales within watersheds and other ecological and social structures.

As Salleh notes:

...an ecological feminist perspective emerges from praxis - action learning.... The global majority of women - being mothers and care givers - are culturally positioned as labour right at the point where humanity and nature interact.... It is certainly no exaggeration to say that the entire machinery of global capital rests on the material transactions of this reproductive labour force...(T)hese agents of complexity are practicing both an alternative economics and an alternative epistemology... The bearers of ecological and embodied debt are thus not simply victims of capitalist patriarchal institutions, they are leaders, and their people's science is one for the global North to emulate" (2009: 7-8).

Especially in times of climate change, this pattern of global organizing and leadership is urgent and compelling.

\section{References}

Adamo, N. 2012. Relatório de estagio: Sistema de abastecimento de água e sameamento do meio: uma analise comparativa. Universidade Eduardo Mondlane, Faculdade de Educação, Mozambique.

Brooks, N., W.N. Adger, and P.M. Kell. 2005. The determinants of vulnerability and adaptive capacity at the national level and the implications for adaptation. Global Environmental Change 15:151-63.

CIDA (Canadian International Development Agency). 2002. Gender equality and climate change: Why consider gender equality when taking action on climate change? Ottawa: Canadian International Development Agency. http://www.acdicida.gc.ca/INET/IMAGES.NSF/vLUImages/Climate\%20change3/\$file/Gend er-2.pdf.

Dessai, S., W.N. Adger, M. Hulme, J. Turnpenny, J. Kohler, and R. Warren. 2004. Defining and experiencing dangerous climate change. Climatic Change 64: 1125.

Elmhirst, R. 2011. Introducing new feminist political ecologies. Geoforum 42: 129-132.

Ensor, J., and R. Berger, eds. 2009. Understanding climate change adaptation: Lessons from community-based approaches. Bourton on Dunsmore, UK: Practical Action Publishing.

Faucheux, S., and C. Hue. 2001. From irreversibility to participation: Towards a participatory foresight for the governance of collective environmental risks. Journal of Hazardous Materials 86: 223-43.Gonçalves, B. Carvalho, B. Cavalcante, C. Gomes Pastor, A.L. Gomes, A.M. Pino Bustamante, C. Yamazaki Saravalle, F. Gonçalves Silva, J.H. Badi Zappala, L. Blaud Ciola, and S.M. Ribeiro. 2008. Agroecologia urbana e práticas sustentáveis. São Paulo: EPARREH. http://www.seaembu.org/docs/FANZINE_2008_Colorido_site.pdf. 
Few, Roger, K. Brown and E.L. Tompkins (2007). Public participation and climate change adaptation: avoiding the illusion of inclusion. Climate Policy 7:1, 4659 .

Hinchcliffe, F., J. Thompson, P. Shah, J. Pretty, and I Guijt, eds. 1999. Fertile ground: The impacts of participatory watershed management. London: Earthscan/IT Publications.

Holland, Alan. 1997. The foundations of environmental decision-making. International Journal of Environment and Pollution, 7 (4), 483-495.

IPCC (Intergovernmental Panel on Climate Change). 2007. Climate change 2007: Synthesis report. Available from: http://www.ipcc.ch.

JFCFC (Jane-Finch Community and Family Centre). 2013. Green Change builds its dream home at 2999 Jane St. http://janefinchcentre.org/content/greenchange-builds-its-dream-home-2999-jane-st (accessed August 19, 2013).

—. 2012. Greening our communities through Live Green Toronto grants. http://www.toronto.ca/livegreen/pdf/jane_finch.pdf.

Lim, B., and E. Spanger-Siegfried. 2004. Adaptation policy frameworks for climate change: Developing strategies, policies and measures. Cambridge: Cambridge University Press and United Nations Development Program.

Lorimer, E. 2011. The Green Change Project story. Unpublished paper, York University.

Ludi, E. Wiggins, S. Jones, L. Lofthouse, J. \& Levine, S. 2014. Adapting development: how wider development interventions can support adaptive capacity at the community level. Community-Based Adaptation to Climate Change: Scaling it Up. London, Earthscan.

Mirza, M.M.Q. 2003. Climate change and extreme weather events: can developing countries adapt? Climate Policy 3: 233-48.

Moraes, A., and Perkins, P.E. 2007. Women, class, and participatory water management in Brazil. International Feminist Journal of Politics 9: 485-93.

Neumayer, E., and T. Plümper. 2007. The gendered nature of natural disasters: the impact of catastrophic events on the gender gap in life expectancy, 1981-2002. Annals of the Association of American Geographers 97: 551-66.

Paavola, J., W.N. Adger, and S. Huq. 2006. Multifaceted justice in adaptation to climate change. In Fairness in adaptation to climate change, ed. W.N. Adger, J. Paavola, S. Huq, and M.J. Mace, 263-78. Cambridge, MA: MIT Press.

Perkins, P.E. 2003. Public participation in ecological valuation: How policies can help it happen. Paper presented at the conference of the Canadian Society for Ecological Economics (CANSEE), Jasper, Alberta, October 16-19.

- 2004. Participation and watershed management: experiences from Brazil. Paper presented at the conference of the International Society for Ecological Economics (ISEE), Montreal, Canada, July 10-14.

Powell, R. 2010. Vision: Centre for Green Change pathways to green jobs program. http://www.nb.lung.ca/downloads/Rosemarie\%20Powell.pdf.

Projeto Bacias Irmãs. 2007a. Agentes comunitarios de saude. Video showing community health groups and activities.

http://www.youtube.com/watch?v=rqg7MMckLcU. 
—. 2007b. Encontro estadual de educação ambiental.Video showing project activities at an environmental education conference. http://www.youtube.com/watch?v=9XzS3oLt-48.

- 2008. Balanço do projeto. São Paulo: ECOAR. http://www.ecoar.org.br/web/files/files/Balanco_do_Projeto_Bacias_Irma s_VERSAOFINAL.pdf.

Rocheleau, D., B. Thomas-Slayter, E. Wangari, eds., 1996. Feminist political ecology: Global issues and local experiences. London: Routledge.

Sagoff, M. 1998. Aggregation and deliberation in valuing environmental public goods: A look beyond contingent pricing. Ecological Economics 24: 213-30.

Salleh, A. 2009. Eco-sufficiency and global justice: Women write political ecology. London/New York/Melbourne: Pluto Press/Spinifex.

Sister Watersheds Project Final Report. 2008. UPCD Tier 2 End-of-Project Narrative Report, May 2008. Available from: www.yorku.ca/siswater. Accessed November 5, 2013.

Sister Watersheds. 2008. Project website: www.yorku.ca/siswater. Accessed October 11, 2011.

Smit, B., and J. Wandel. 2006. Adaptation, adaptive capacity and vulnerability. Global Environmental Change 16: 282-92.

Teixeira, D. de Lima, M. Ferraz Duarte, and P. Morimoto. . 2008. Manual de metodologias participativas para o desenvolvimento comunitário. São Paulo: ECOAR. http://www.paulofreire.org/wpcontent/uploads/2012/CCP_Mat_Ref_Livro s/manual_de_metodologias_participativas_para_o_desenvolvimento_comun itario_VERSC3830FINAL.pdf.

Terry, G., ed. 2009. Climate change and gender justice. Rugby, UK: Practical Action Publishing in association with Oxfam GB.

Todd, A. 2011. Climate change and water governance in the greater Toronto area. http://ccaa.irisyorku.ca.

Toulmin, C. 2010. Climate change in Africa. London: Zed Books.

UN Habitat (United Nation Human Settlements Program). 2010. Climate change assessment for Maputo, Mozambique. Cities and Climate Change Initiative. Nairobi, Kenya. http://www.unhabitat.org/pmss/getElectronicVersion.aspx?nr=2977\&alt= 1 .

van den Hove, S. 2000. Participatory approaches to environmental policy-making: The European Commission climate policy process as a case study. Ecological Economics 33: 457-72.

Wilson, M.A. and R.B. Howarth. 2002. Discourse-based valuation of ecosystem services: Establishing fair outcomes through group deliberation. Ecological Economics 41: 431-43. 
${ }^{\mathrm{i}}$ The authors acknowledge support from the Canadian International Development Agency through the Association of Universities and Colleges of Canada (Sister Watersheds Project in Brazil, 2002-2008) and the International Development Research Centre and U.K. Department for International Development (Climate Change Adaptation in Africa project, 2010-2012). This chapter is based on an article which appeared in the Journal of Cleaner Production, vol. 60, December 2013, pp. 188-194, "Women and Water Management in Times of Climate Change: Participatory and Inclusive Processes" by Patricia Figueiredo and Patricia E. Perkins, and is used with permission from Elsevier.

ii See Jane-Finch community website at http://www.jane-finch.com/about.htm.

iii See Green Change Project slide show presentation at https://www.google.ca/search?q=green+change+project\&oq=green+change+project\&aqs= chrome..69i57j0l2.2776j0j8\&sourceid=chrome\&espv=210\&es_sm=91\&ie=UTF-8.

${ }^{\text {iv }}$ Majora Carter is a South Bronx activist and international speaker who advocates and organizes for green urban renewal in low-income neighborhoods. She won a MacArthur "genius" grant in 2005. See http://www.ted.com/speakers/majora_carter.html, http://www.majoracartergroup.com/, http://yorkwestadvocate.wordpress.com/2011/02/22/enviornmental-activist-speaksabout-green-change-in-our-community/, and http://www.nytimes.com/2013/04/05/nyregion/a-hero-of-the-bronx-majora-carter-isnow-accused-of-betraying-it.html (accessed 5 November 2013).

${ }^{\mathrm{v}}$ See the project's reports at http://ccaa.irisyorku.ca. 